\title{
ПСИХОЛОГІЧНИЙ АНАЛІЗ ПРОФЕСІЙНОЇ ДІЯЛЬНОСТІ ПОЛІЦЇ̈ ОСОБЛИВОГО ПРИЗНАЧЕННЯ
}

Удк: 159.9:351.749

\begin{abstract}
Ярема Наталія Юрї̈вна
Кандидат психологічних наук, провідний науковий співробітник, Державний науково-дослідний інститут Міністерства внутрішніх справ Украӥни, м. Київ (Україна)
\end{abstract}

\section{Пампура Ігор Іванович}

Старший науковий співробітник, Державний науково-дослідний Міністерства внутрішніх справ Украӥни, м. Київ (Украӥна)

\begin{abstract}
Анотація. У статті представлено результати аналізу науково-теоретичних та практичних джерел з проблеми діяльності полічії особливого призначення. Визначено психологічні характеристики, які вирізняють ї̈ серед інших видів професійної діяльності. Представлено перелік психологічних складових причин загибелі та поранень прачівників спецпідрозділів під час виконання службових обов'язків. Розкрито особливості механізму сприйняття професійних ситуацій як екстремальних, а також фактори, щуо обумовлюють таке сприйняття. Описано особливості негативного та позитивного впливу екстремально-психологічних чинників на психічні процеси полічейських. Охарактеризовано зміст психологічної стійкості бійців до стресових факторів в умовах виконання професійних завдань, а також складові системи особистої професійної безпеки.
\end{abstract}

Ключові слова: полічія особливого призначення, полічейський, професійна діяльність, екстремальні умови, психологічна стійкість, психологічна готовність, особиста професійна безпека.

Виконання службових обов'язків працівниками поліції особливого призначення пов'язано з високим ступенем ризику, потребує великого напруження психічних і фізичних ресурсів, прийняття відповідальних рішень в умовах дефіциту часу. Робота в умовах підвищеного ризику, реальної загрози життю та здоров'ю може призводити до того, що працівники нерідко переживають події, що виходять за межі звичайного досвіду.

Діяльність бійців спецпідрозділів, пов'язана з ризиком для життя і характеризується 
частим виникненням екстремальних ситуацій, здійснюється в напружених мінливих умовах, не регламентована жорстким розпорядком дня, пов'язана 3 постійним носінням і можливим застосуванням зброї, з реалізацією владних повноважень. Серед завдань, що виконує поліція особливого призначення, визначаються [8]: розробка, підготовка та проведення спеціальних операцій із захоплення небезпечних злочинців; припинення правопорушень, що вчиняються учасниками злочинних угрупувань; звільнення заручників; здійснення силової підтримки під час проведення оперативнорозшукових заходів, слідчих (розшукових) та негласних слідчих (розшукових) дій, а також заходів забезпечення кримінального провадження; надання підтримки іншим підрозділам поліції з метою забезпечення переважаючої вогневої потужності над правопорушниками; участь в антитерористичних операціях, що проводяться Антитерористичним центром при Службі безпеки України.

Різним аспектам проблеми професійної та функціональної надійності в системі правоохоронних органів присвячені роботи вітчизняних та зарубіжних науковців, зокрема, В. Г. Андросюка, Л. М. Балабанової, О. М. Бандурки, В. І. Барка, В. А. Бодрова, С. П. Бочарової, В. Л. Васильєва, М. І. Єнікєєва, В. О. Криволапчука, В. О. Лефтерова, М. Г. Логачова, К. Макнаба, В. С. Медведєва, О. Д. Сафіна, О. Г. Сиропятова, Ю. В. Слядневої, О. М. Столяренка, В. О. Татенка,
О. В. Тімченка, О. М. Цільмак, О. В. Чуфаровського, С. І. Яковенка та інших. У працях науковців висвітлені лише окремі питання психологічних особливостей діяльності фахівців правоохоронної діяльності в екстремальних умовах.

Метою статті $є$ аналіз та узагальнення напрацювань науковців та практиків 3 проблеми психологічних аспектів професійної діяльності фахівців професій екстремального характеру, а також розкриття особливостей діяльності працівників підрозділів поліції особливого призначення.

Узагальнення характеристик сучасної поліцейської діяльності, здійснене науковцями, а також власні дослідження дозволили визначити основні їі психологічні характеристики, які вирізняють іï серед інших видів професійної діяльності. Серед них: спрямованість на забезпечення законності і дотримання прав людини; необхідність швидко приймати рішення і висока відповідальність за них; владні повноваження; емоційна насиченість і напруженість, психофізичні навантаження; наявність організаційних і екстремальних чинників; специфічність об'єктів професійної діяльності; толерантність до невизначених ситуацій; важливість ефективного лідерства і командної взаємодії в підрозділах.

\section{Характерними соціально-} психологічними особливостями професійної діяльності працівників поліції особливого призначення також $є$ високий рівень відпові- 
дальності та інтенсивність внутрішньо групової взаємодії. Зміст службових завдань визначається складністю та різнобічністю, а механізм їх реалізації пов'язаний з дефіцитом часу на усвідомлення інформації та прийняття рішень [7].

Так, серед найбільш поширених психологічних складових причин загибелі та поранень працівників спецпідрозділів під час виконання службових обов'язків науковці та практики визначають [4]:

- прорахунки планування заходів оперативно-розшукової діяльності;

- недоліки здійснення розвідувальних заходів;

• неповнота інформаційно-аналітичного опрацювання операцій;

- дефіцит часу при прийнятті оперативних рішень;

- недостатньо кваліфіковані дії працівників під час виконання запланованих заходів.

Слід розуміти, що сприйняття ситуації як екстремальної обумовлюється суб'єктивними показниками особистості, які базуються на ціннісно-змістовній, афективній сферах особистості а також власному набутому досвіді. На думку Л. А. Китаєва-Смика, екстремальна ситуація пред'являє людині вимоги, які вона сприймає як такі, що перевищують їі можливості, що може або призвести до дистресу, або ж дозволить реалізовувати свої можливості та досягти необхідної мети [6].

Французький вчений П. Фрес вважає, що стресогенним моментом є не сама по собі ситуація, а співвідношення в цій ситуації між мотивами і можливостями суб'єкта діяти адекватно. Залежно від ступеня відповідності мотивації можливостям індивіда науковець виділяє два типи стресових ситуацій. Перший тип характеризується умовами, за яких суб'єкт не здатний або не готовий діяти (відсутність попереднього досвіду, незвичайність чи неочікуваність ситуації). Другий тип передбачає наявність надвисокого рівня мотивації, яка викликає або сильну схвильованість, напруження, або ж розрядку у вигляді сміху, метушливості тощо [9].

Ефективність же діяльності бійців в екстремальних умовах, на думку В. I. Малічевського, залежить від таких факторів [9]:

1. Інтенсивності і сили подразника, тобто поступового чи раптового зростання стресового фактора, що впливає на особистість. До певної межі такий вплив є позитивним, при перевищенні порогу він дезорганізує діяльність.

2. Функціонального та психологічного стану організму. Наявність соматичних захворювань, психічних травм зменшують адаптивні можливості і ускладнюють виконання діяльності.

3. Індивідуально-психологічних особливостей. Сукупність психофізіологічних властивостей та достатній рівень розвитку психологічних якостей, оптимальний рівень тривож- 
ності, стійкість до перенапруження та небезпеки обумовлюють психологічну надійність працівника.

4. Психологічна підготовленість. Наявність відповідного досвіду та спеціальна підготовленість до дій у різних ситуаціях професійної діяльності.

Так, у підготовлених до екстремальних ситуацій працівників період адаптації до раптового виникнення небезпеки досить короткий порівняно з непідготовленими. Більш ефективними виявляються ті, хто чітко усвідомлює свої завдання і основну мету діяльності, інші ж, кого охоплює страх та безконтрольні емоції, не в змозі діяти ефективно [13].

В цілому екстремальні ситуації викликають зміни в когнітивній, емоційній, поведінкових сферах психіки недостатньо підготовлених працівників.

Так, у когнітивній сфері на рівні процесів спостерігаються порушення відчуттів, сприйняття, уваги, мислення, пам'яті, а також процесів прийняття рішення, контролю, регуляції власних емоційних станів, може виникати відмова моторних функцій. Так, практично у всіх стресових ситуаціях присутній ефект «звуження свідомості», який допомагає відібрати необхідну інформацію для прийняття правильного рішення. Проте такий феномен може обумовлювати й виникнення надмірного «звуження свідомості», що призводить до відсіювання необхідної інформації, внаслідок чого може виникнути дезорієнтація. Ефект «тунельного бачення» $є$ природною реакцією людини, за якої не сприймаються події, що відбуваються за межами «тунелю». Таке скорочення поля зору може бути смертельно небезпечним для працівника, особливо якщо правопорушник заходить з боку і відкриває вогонь. Явище «часткової глухоти» може виникати у працівників, які перебувають в екстремальній ситуації і переживають страх за своє життя. В такому стані головний мозок відключає всі «сторонні» шуми. Слух повертається лише після закінчення дії подразника, тому небезпека такого стану пов'язана $з$ тим, що працівник може не почути попередження колег.

Велике психологічне перенапруження може спровокувати також раптовий шок, який супроводжується такими негативними фізіологічними реакціями: тремтіння рук, ніг, дискоординація рухів, аж до прояву стану заціпеніння та ін.

В умовах екстремальних ситуацій може змінюватися і сприйняття часу (час ніби розтягується або стискається), тобто відбувається викривлення часового сприйняття подій, що відбуваються [13].

Характерним для екстремальних ситуацій часто буває невірне «дозування» своїх зусиль. Так, фахівці з вогневої підготовки відзначають феномен «конвульсивної хватки» зброї, яка виникає при застосуванні вогнепальної зброї. Цей феномен виражається в дуже міцному утриманні пістолета і натиску на спу- 
сковий гачок 3 великим зусиллям, що призводить до виникнення інтенсивного тремору та різкого руху рук під час натискання на спусковий гачок [9].

Емоційно-вольова сфера характеризується такими проявами, як: тривожність; страх, крайнім вираженням якого є жах, панічний стан; безпідставна агресія; гнів; відчуття провини; туга, пригніченість, апатія. Відбувається послаблення вольових процесів. Стає складніше виконувати діяльність, що вимагає задіяння емоційних, розумових або фізичних резервів. Так, у діяльності працівників державної служби охорони, значна кількість хибних викликів протягом чергування на початку чергування викликає стан мобілізаційної готовності, а наприкінці чергування зумовлює роздратування та зниження пильності [6].

Внаслідок порушення почуття безпеки, втрачається довіра до людей i, в цілому, до світу. Також може спостерігатися зниження значущості ціннісних орієнтацій. Моральні та матеріальні цінності, які були раніше значними, здаються непотрібними, цілі, які надихали, - малозначущими або помилковими.

Довготривалий стрес може посилити готовність підкорятися зовнішнім вказівкам, схильність узгоджувати свої дії $з$ директивною інформацією, що може призводити до пасивності. В таких умовах може зростати емоційне напруження. Це відчувається людиною як непомітне або часом збільшене почуття незадоволеності собою або оточуючими, як дратівли- вість, образливість, що проявляється 3 будьякого приводу, часто і без приводу, як схильність зосереджуватися на негативних моментах та перебільшувати їх значення. Особливо небезпечним $є$ реалізація зазначеного феномену у формах підвищеної агресивності чи перебільшення небезпеки, що може обумовити ситуацію неадекватного застосування працівниками засобів примусу при виконанні професійних завдань [6].

У поведінковій сфері часто спостерігається дезорганізація поведінки, що полягає або у втраті контролю, цілеспрямованості поведінки (виникає безцільна активність), або ж у пасивності. Втрачаються творча здатність, адекватне розуміння того, що відбувається; поведінка стає шаблонною і не повністю відповідає обставинам. При зростанні інтенсивності дії стресових факторів починають з'являтися помилки навіть в відпрацьованих уміннях і навичках, їх кількість поступово збільшується; результативність діяльності швидко зменшується. У разі досягнення граничного напруження 3'являються грубі помилки; можуть спостерігатися випадки боягузтва, відмови від виконання ризикованих доручень, обман, нечесність, безвілля та ін. Може також розвиватися схильність до неприйняття будьяких змін (нової вказівки керівника, прохання партнера, змін у оперативній інформації). Внаслідок цього в стресових, критичних умовах працівник несвідомо може ігнорувати певну інформацію [6]. 
У взаємодії в підрозділах може спостерігатися агресивна поведінка (часто необгрунтована), конфлікти, пошук винних, відчуження. Може виникати незадоволеність психологічним навантаженням, пов'язана з відповідальністю за інших членів колективу. Це може призводити до уникнення відповідальності за результати спільної діяльності. Негативне ставлення до колег може проявлятися у вигляді зневажливого відношення до дисципліни, до розкладу робочого часу та ін. [6].

Негативні явища можуть виникати і в недостатньо підготовлених групах: з'являються нездорові і песимістичні настрої, чутки, невдоволення, негативні думки, послаблюється дисципліна, спостерігаються порушення статутних і службових норм поведінки, конфлікти у взаєминах, паніка.

Однак, окрім негативного впливу екстремально-психологічні чинники здійснюють й позитивний вплив на психіку бійця, за умови достатнього рівня його моральної і професійно-психологічної підготовленості. У такому випадку психічна діяльність в екстремальних умовах характеризується [12]:

- загостреним почуттям обов'язку, відповідальності і рішучості, у поєднанні з бажанням безумовно і якісно вирішувати поставлені завдання;

- повною самомобілізованістю, застосуванням наявних резервів в ході вирішення завдань;

- підвищеною енергійністю і активніс- тю, наполегливістю і завзятістю у досягненні цілей;

• прагненням досягти результату;

- високим рівнем уважності, спостережливості, швидкою і чіткою мисленевою діяльністю;

- зібраністю і готовністю до несподіванок, до швидких реакцій в умовах змін обстановки і виникнення небезпеки;

- стійкістю до тимчасових невдач і ін.

Позитивні зміни мають і груповий характер. Так, в підрозділах з високим рівнем підготовленості спостерігаються позитивний морально-психологічний клімат, оптимістичний настрій, взаємини побудовані відповідно до професійних інтересів, існують злагоджена взаємодія, взаєморозуміння, взаємодопомога, прояви солідарності, взаємної підтримки, дотримання професійних традицій та ін.

Як вже зазначалося, діяльність спеціальних підрозділів пов'язана 3 ризиком для життя, здійснюється в напружених мінливих умовах, тому важливого значення набуває наявність сформованої психологічної стійкості бійців до стресових факторів в умовах виконання професійних завдань.

Психологічна стійкість $є$ комплексною характеристикою, синтезом окремих якостей $\mathrm{i}$ здібностей, що дозволяють особистості протистояти несприятливим психологічним обставинам при вирішенні професійних завдань, не знижувати працездатність під їх впливом. Вона підтримується внутрішніми та зовнішніми 
ресурсами (чинниками).

Серед внутрішніх або особистісних чинників розглядають, в першу чергу, свідомість, тобто розуміння і відчуття сенсу життя, осмисленість діяльності й поведінки, відсутність ірраціональних ідей і життєвих принципів, установку на можливість розпоряджатись власним життям, віру у можливість досягнення поставлених цілей тощо. Також розвинута вольова саморегуляція, здатність до подолання труднощів, стійкість групових ролей, стабільний і достатньо високий статус в соціумі. До внутрішніх ресурсів належить і самооцінка, яка виражається у адекватному ставленні до себе, узгодженості Я-реального і Яідеального, впевненість в собі і відчутті незалежності.

У якості зовнішніх чинників психологічної стійкості виступають фактори соціального середовища, що підтримують рівень самооцінки особистості, сприяють її самореалізації, зберігають адаптивний потенціал та енергетичні ресурси. Це може бути допомога і підтримка 3 боку соціального оточення, близьких $\mathrm{i}$ друзів, колег по роботі $[11 ; 14]$.

В тих випадках, коли чинники соціального середовища підтримують достатньо високу самооцінку, адаптивний потенціал та енергетичні ресурси організму, сприяють самоактуалізації, це сприяє більш високому рівню психологічної стійкості, надійності і працездатності поліцейського. Якщо ж соціальні чинники діють негативно, знижують адаптивні можливості та енергетичний потенціал, обмежують ії самореалізацію, позбавляють емоційної підтримки, тоді вони знижують психологічну стійкість, спричиняють виникнення станів дезадаптації.

Забезпечити збереження життя, фізичне і психічне здоров'я, а також підтримку високого рівня ефективності професійних дій працівників підрозділів поліції особливого призначення дозволяє система правових, спеціальних, тактичних, педагогічних і психологічних заходів, яка являє собою особисту професійну безпеку. Вона грунтується на достатньому рівні професійної підготовленості бійців, який передбачає також володіння безпечними методами професійної діяльності, сформовану особистісну установку на виживання, психологічні якості, що дозволятимуть адекватно оцінювати обстановку, управляти почуттям страху, приймати швидкі і правильні рішення і не втрачати самовладання в небезпечних ситуаціяX.

Забезпеченню професійної безпеки в умовах ризику для життя сприяють наявність комплексу особистісних якостей, серед яких $[5]:$

Чітке усвідомлення цілей професійної діяльності (знати заради чого ризикувати життям).

Професійна підготовленість (знання та вміння ефективно діяти в ситуаціях екстремального характеру).

Стійкість до впливу стресових факторів 
(наявність необхідних психофізіологічних властивостей, сформована професійнопсихологічна готовність до дій у критичних $\Rightarrow$ ситуаціях).

Впевненість в собі при вирішенні професійного завдання.

Впевненість у надійності спорядження, технічних засобів, тощо.

Рішучість (здатність швидко приймати вірне рішення.)

Ефективність в діях. (здатність до антиципації (передбачення) результату своїх дій).

Емоційна стійкість (здатність регулювати власний психоемоційний стан в екстремальних ситуаціях).

Фізична підготовленість (наявність необхідних фізичних ресурсів, необхідних для виконання професійного завдання).

Здатність до командної взаємодії (ефективних злагоджених дій в умовах виконання завдань групового характеру).

Готовність до виправданого ризику.

А серед напрямків особистісного розвитку та вдосконалення здатності до професійної безпеки науковці та практики виділяють [1]:

$\Rightarrow \quad$ формування віри в власну невразливість та розвиток установки на виживання у небезпечних умовах діяльності;

$\Rightarrow$ розвиток професіоналізму та зміцнення впевненості у безпомилковості власних дій у кризових ситуаціях;

$\Rightarrow$ реальне або мисленеве моделювання не- безпечних ситуацій, що супроводжується переживанням вираженого страху;

підтримка позитивних емоцій та переживань після ризикованих дій у небезпечних ситуаціях, що завершилися успішним результатом при вирішенні службового завдання;

$\Rightarrow$ набуття навичок аутогенного тренування, концентрації та медитації.

Суттєву роль у забезпеченні особистої професійної безпеки є формування установки на виживання, як готовності та схильності працівника до цілеспрямованої, надійної та спрямованої на самозахист форми здійснення професійної діяльності. Вона включає три компоненти: пізнавальний (усвідомлення реальності виникнення небезпечних ситуацій у професійній діяльності та знання тактики безпечної поведінки у процесі реалізації професійних завдань); емоційно-оціночний (внутрішнє налаштування на безпечні форми поведінки) та поведінковий (готовність до вибору та реалізації тактики безпечної поведінки у професійній діяльності).

Формування стійкої установки на виживання у працівників підрозділів поліції особливого призначення має передбачати одночасне формування готовності до адекватного та мотивованого ризику, подолання почуття страху, а також розвиток здатності до прогнозування та пильності у поведінці.

Оскільки страх може мати паралізуючий ефект на вольові процеси, часто призводи- 
ти до спонтанних, непродуманих і хаотичних дій, це призводить до зниження надійності і ефективності вирішення професійних завдань [12]. Він може проявлятися у різних формах від побоювань, остраху, переляку до жаху, що призводить до втрати цілеспрямованості в поведінці, домінуючого прагнення приховатися від джерела небезпеки.

Страх базується на інстинкті самозбереження і має захисний характер, тому лише визнавши його нормальною реакцією на небезпечну ситуацію, можна навчитись управляти ним. За такої умови можливо позбавитись від гнітючого страху перед самою можливістю боятися (справжня хоробрість проявляється у людей, які легко визнають свій страх, що дозволяє їм ефективно діяти в реальних умовах небезпеки). Окрім того, вірогідність вірних дій існує за умови чіткого усвідомлення небезпеки та планування адекватних заходів щодо вирішення ситуації. Будь-яка активність також зменшує інтенсивність страху. Людина, позбавлена можливості вільно діяти, відчуває страх сильніше, ніж та, яка може захищатися.

Вважається, що страх неможливо подолати логічними поясненнями, самонаказами подумки, вольовими зусиллями. Серед шляхів розвитку самовладання та управління почуттям страху виділяють виховання та оволодіння спеціальними психотехнічними прийомами управління страхом.

Можливе виникнення небезпеки, настання несприятливих наслідків в результаті дій працівників у професійній діяльності поліції особливого призначення $є$ характеристикою ризику. Суб'єктивне сприйняття ризику залежить від різноманітних факторів, серед яких головними визначають: вагомість наслідків, розподіл загрози в часі, контрольованість ситуації, добровільність у прийнятті рішення про ризиковану поведінку, а також ступінь новизни для працівника поставленого завдання [10]. Ризик характеризується можливістю вибору між менш чи більш небезпечними для працівників варіантів поведінки, які відрізняються за ступенем їх ефективності з точки зору досягнення результатів діяльності. Часто ризикована поведінка дозволяє досягти службових цілей швидше із задіянням менших ресурсів.

Серед факторів, що впливають на вибір тієї чи іншої форми ризикованої поведінки або на відмову від ризику розрізняють взаємопов'язані між собою соціальні, психологічні та соціально-психологічні детермінанти [3].

Несприятливою умовою щодо обгрунтованості і адекватності поведінки в небезпечній ситуації може стати індивідуальна схильність працівника до ризику. Схильність до ризику науковцями, як правило, розглядається як риса особистості що пов'язується з наявністю в структурі особистості таких складових, як прагнення до нових яскравих відчуттів, гнучкість мислення, потреба в самоствердженні, а також виражені тривожність та агресивність тощо. 
В небезпечних умовах поліцейські залежно від своєї схильності до ризику можуть обирати різні форми поведінки. У деяких, об'єктивно існуюча небезпека може блокувати вольові процеси, змушуючи відмовитися від активних дій, інших, навпаки, вона мобілізує, дає додатковий прилив сил $[10 ; 15]$.

На відміну від схильності до ризику, як особистісної риси, існує поняття готовності до ризику, що вказує на зв'язок цього показника не стільки з індивідуальними проявами, скільки 3 конкретною ситуацією, відображаючи, таким чином, мотиваційний аспект особистості. Позитивний результат в умовах ризику значною мірою пов'язаний із ступенем обгрунтованості або необгрунтованості прийнятого рішення про вибір ризикованої поведінки. Так, обгрунтований ризик передбачає адекватну оцінку поліцейським співвідношення між очікуваним успіхом і очікуваною невдачею. У цьому випадку йому необхідно мати: адекватний рівень домагань та самооцінки; достатній досвід професійної діяльності, зокрема в екстремальних умовах; розвинуте почуття відповідальності за власні дії та несуперечливу мотивацію до діяльності; а також здатність до адекватного реагування в екстремальній ситуації.

Певний вплив на прийняття рішення про ризиковану поведінку можуть мати пережиті у минулому ситуації небезпеки. Наприклад, особа, що отримала у небезпечній ситуації поранення або психотравму, втрачає впевненість в можливості запобігання нещасних випадків у майбутньому. Така ситуація вимагає психотерапевничного втручання. Або, працівник, переживши небезпеку, стає більш передбачливим, обережним, у нього розвивається здатність до мотивованого та обгрунтованого ризику [12].

Отже, поведінка працівника в психологічно напружених та екстремальних ситуаціях визначається його професійною компетентністю, мотивацією і особистою психологічною підготовленістю, здатністю до професійної безпеки. Основними психологічними критеріями визначення ступеня екстремальності умов професійної діяльності для працівника спецпідрозділу $є$ наявність реальної загрози для життя та здоров'я, висока ціна помилки в діяльності, рівень особистісної значимості виконання поставленого завдання, систематичне виникнення стресових станів, наявність монотонії в діяльності тощо. Тому, важливою передумовою високої надійності особового складу підрозділів поліції особливого призначення $є$ сформованість у бійців психологічної готовності до виконання професійних завдань, наявність комплексу необхідних психофізіологічних властивостей, професійно-важливих якостей, постійне професійне вдосконалення працівників а також розвинута командна взаємодія в підрозділі. Подальшого ж дослідження потребують питання визначення чітких критеріїв психологічної придатності до служби в підрозділах, а також прогнозування успішності та неуспішності професійної діяльності. 


\section{Перелік використаних джерел:}

1. Адаев А. И. Оценка и прогноз психологической готовности сотрудников органов внутренних дел МВД России к деятельности в экстремальных ситуациях: дис. ... канд. психол. наук: 19.00.06: Санкт-Петербург, 2004. 197 c.

2. Александровский Ю. А. Психология екстремальных ситуаций: Хрестоматия / Сост. А.Е. Тарас, К.В. Сельченок. Минск.: Харвест, 1999. С. 154-165.

3.Альгин А.П. Риск и его роль в общественной жизни, М.: Мысль, 1989. 188 с.

4. Ануфрісв М. І., Ірхін Ю.Б., Курко М.Н., Нещерет Т.В., Омельченко С.В., Синявський В.В., Шаповалов О.В. Професіографічна характеристика основних видів діяльності в органах внутрішніх справ України (кваліфікаційні характеристики професій, професіограми основних спеціальностей): Довідник. К.: МВС України; КІBC, 2003. 80 c.

5. Духновский C. B. Брюзгин А.А. Психологическая устойчивость как условие преодоления критических ситуаций / Вестник Курганского государственного университета. Серия: Физиология, психофизиология, психология и медицина. 2008. № 11. С. 131-134.

6. Китаев-Смик Л. А. Психология стреса. М.: Наука, $1983.368 \mathrm{c}$.

7. Корнєв О. М. Професійно-психологічна підготовка працівників підрозділів швидкого реагування міліції України : Автореф. дис. канд. психол. наук : 19.00.06 / Нац. акад. внутр. справ України МВС України. К., 2001. $18 \mathrm{c}$.

8. Корпус Оперативно-Раптової Дії Національної поліції України: сайт. URL: https://www.police.gov.ua/KORD

9. Малічевський В. I. Психологічні методи вогневої підготовки в підрозділах органів внутрішніх справ МВС України: дис. канд. психол. наук: 19.00.06 / Національна академія внутрішніх справ України. К., 2003. 263 с.

10. Петимко А. И. Отношение к риску как компонент психологической готовности к профессиональной деятельности сотрудников МЧС России: дис. канд. психол. наук: 05.26.03; Санкт-Петербургский университет государственной противопожарной службы МЧС Р. СанктПетербург, 2010. 215 с.

11. Психологическое обеспечение деятельности органов внутренних дел в экстремальных условиях: методическое пособие. М.: ЦЩКП МВД России, 2001. 224 с.

12. Столяренко А. М. Прикладная юридическая психология. М.: ЮНИТИ-ДАНА, 2001. 639 с.

13. Танаев В. П. Моделирование как метод оптимизации деятельности операторов АСУ / Психологические факторы операторской деятельности / под ред. А.И. Галактионова. М.: Наука, 1988. 200 с.

14. Beard J. P. The Diagnostic and Treatment of Mental Illness / J. Beard, D. Hayter, E. Shenkar. Detroit: Wayne State University Press, 1989. 214 p.

15. Eysenk S. B. G. et al. Age norms for impulsiveness, venturesomeness and empathy in adults / Person. individ. Diff. 1985. Vol. 6. N. 5. P. 613-619.

\section{References (Transliteration):}

1. Adaev A. I. Otsenka i prognoz psikhologicheskoy gotovnosti sotrudnikov organov vnutrennikh del MVD Rossii $\mathrm{k}$ deyatelnosti $\mathrm{v}$ ekstremalnykh situatsiyakh: dis. ... kand. psikhol. nauk: 19.00.06: Sankt-Peterburg, 2004. 197 c.

2. Aleksandrovskiy Yu. A. Psikhologiya ekstremalnykh situatsiy: Khrestomatiya / Sost. A.Ye. Taras, K.V. Selchenok. Minsk.: Kharvest, 1999. S. 154-165.

3. Algin A. P. Risk i ego rol v obshchestvennoy zhizni, M.: Mysl, 1989. $188 \mathrm{~s}$.

4. Anufriiev M. I., Irkhin Yu.B., Kurko M.N., Neshcheret T.V., Omelchenko S.V., Syniavskyi V.V., Shapovalov O.V. Profesiohrafichna kharakterystyka osnovnykh vydiv diialnosti v orhanakh vnutrishnikh sprav Ukrainy (kvalifikatsiini kharakterystyky profesii, profesiohramy osnovnykh spetsialnostei): Dovidnyk. K.: MVS Ukrainy; KIVS, 2003. 80 s.

5. Dukhnovskiy S. V. Bryuzgin A.A. Psikhologicheskaya ustoychivost kak uslovie preodoleniya kriticheskikh situatsiy / Vestnik Kurganskogo gosudarstvennogo universiteta. Seriya: Fiziologiya, psikhofiziologiya, psikhologiya i med- 
itsina. 2008. № 11. S. 131-134.

6. Kitaev-Smik L. A. Psikhologiya stresa. M.: Nauka, 1983. 368 s.

7. Korniev O. M. Profesiino-psykholohichna pidhotovka pratsivnykiv pidrozdiliv shvydkoho reahuvannia militsii Ukrainy : Avtoref. dys. kand. psykhol. nauk : 19.00.06 / Nats. akad. vnutr. sprav Ukrainy MVS Ukrainy. K., 2001. $18 \mathrm{c}$.

8. Korpus Operatyvno-Raptovoi Dii Natsionalnoi politsii Ukrainy: sait. URL: https://www.police.gov.ua/KORD

9. Malichevskyi V. I. Psykholohichni metody vohnevoi pidhotovky v pidrozdilakh orhaniv vnutrishnikh sprav MVS Ukrainy: dys. kand. psykhol. nauk: 19.00.06 / Natsionalna akademiia vnutrishnikh sprav Ukrainy. K., 2003. $263 \mathrm{~s}$.

10. Petimko A. I. Otnoshenie $\mathrm{k}$ risku kak komponent psikhologicheskoy gotovnosti $\mathrm{k}$ professionalnoy deyatelnosti sotrudnikov MChS Rossii: dis. kand. psikhol. nauk: 05.26.03; Sankt-Peterburgskiy universitet gosudarstvennoy protivopozharnoy sluzhby MChS R. SanktPeterburg, 2010. $215 \mathrm{~s}$.

11. Psikhologicheskoe obespechenie deyatelnosti organov vnutrennikh del $\mathrm{v}$ ekstremalnykh usloviyakh: metodicheskoe posobie. M.: TsShchKP MVD Rossii, 2001. 224 s.

12. Stolyarenko A. M. Prikladnaya yuridicheskaya psikhologiya. M.: YuNITI-DANA, 2001. $639 \mathrm{~s}$.

13. Tanaev V. P. Modelirovanie kak metod optimizatsii deyatelnosti operatorov ASU / Psikhologicheskie faktory operatorskoy deyatelnosti / pod red. A.I. Galaktionova. M.: Nauka, 1988. $200 \mathrm{~s}$.

14. Beard J. P. The Diagnostic and Treatment of Mental Illness / J. Beard, D. Hayter, E. Shenkar. Detroit: Wayne State University Press, 1989. 214 p.

15. Eysenk S. B. G. et al. Age norms for impulsiveness, venturesomeness and empathy in adults / Person. individ. Diff. 1985. Vol. 6. N. 5. P. 613-619.

\section{Yarema Nataliia}

Phd, leading researcher State Research Institute of the Ministry of Internal Affairs of Ukraine, Kyiv (Ukraine)

\section{Pampura Igor}

Senior researcher, State Research Institute of the Ministry of Internal Affairs of Ukraine, Kyiv (Ukraine)

\section{PSYCHOLOGICAL ANALYSIS OF PROFESSIONAL ACTIVITY SPECIAL POLICE FORCES}

\section{ABSTRACT}

The activities of special police forces, associated with the risk to life and characterized by frequent emergencies of extreme situations, is carried out under tense, changing conditions, not regulated by the rigorous schedule of the day, associated with constant wear and possible use of weapons, with the power above other.

Different aspects of the problem of professional and functional reliability in the system of law enforcement are dedicated to the work of domestic and foreign scholars, whose works cover only certain issues of psychological peculiarities of the activities of law enforcement officers in extreme conditions.

The main psychological characteristics that distinguish the professional activity of the special police forces among other types of professional activity are: the focus on ensuring the legality and observance of human rights; the need to quickly make decisions and have a high responsibility for them; power of attorney; emotional saturation and tension, psychophysical load; the presence of organizational and extreme factors; specificity of objects of professional activity; 
tolerance to uncertain situations; the importance of effective leadership and team interaction in the divisions.

Among the most common psychological constituents of the causes of deaths and injuries of employees of special units during the performance of official duties determine: the miscalculation of planning operational activities; shortcomings in the implementation of intelligence activities; incompleteness of informational and analytical processing of operations; shortage of time when making operational decisions; insufficiently qualified actions of employees during the execution of the planned activities.

It should be understood that the perception of the situation as extreme is subjective, which are based on the value-sense, affective areas of the individual and his own experience. In general, extreme situations cause negative changes in the cognitive, emotional, behavioral spheres of the psyche. However, in addition to the negative effects of extreme-psychological factors, they also have a positive effect on the psyche of the police officers, provided that they have a sufficient level of moral and occupationalpsychological readiness.

Since the activity of special police units is associated with a risk to life, it is carried out under tense and changing conditions, therefore the presence of the formed psychological stability of fighters to stress factors in the conditions of fulfilling professional tasks becomes of paramount importance.
To ensure the preservation of life, physical and mental health, as well as the maintenance of a high level of efficiency of professional activities of employees of special police units, allows the system of legal, special, tactical, pedagogical and psychological measures that called personal professional security. It is based on a sufficient level of professional preparedness of fighters, which also includes the possession of safe professional practices, the formation of a personalized survival facility, and psychological qualities that will allow an adequate assessment of the situation, the management of a sense of fear, making quick and correct decisions and not losing self-control in dangerous situations.

Consequently, the behavior of an employee in psychologically stressful and extreme situations is determined by his professional competence, motivation and personal psychological readiness, ability to professional security. An important prerequisite for the high reliability of the personnel of special police units is the formation of psychological readiness for fighters to perform professional tasks, the presence of a complex of necessary psychophysiological properties, professional qualities, continuous professional development of employees, and also developed team interaction in the unit.

Further research requires the definition of clear criteria for psychological fitness for service in the divisions, as well as the prediction of the success and failure of the professional activities of specially trained police officers. 
Key words: special police forces, police officer, professional activity, extreme conditions, psychological stability, psychological readiness, personal professional safety.

\section{Ярема Наталия Юрьевна}

Кандидат психологических наук, ведущий научный сотрудник, Государственньй научно-исследовательский институт Министерства внутренних дел Украинь, г. Киев (Украина)

\section{Пампура Игорь Иванович}

Старший научный сотрудник, Государственный научно-исследовательский институт Министерства внутренних дел Украины, г. Киев (Украина)

\section{ПСИХОЛОГИЧЕСКИЙ АНАЛИЗ ПРОФЕССИОНАЛЬНОЙ ДЕЯТЕЛЬНОСТИ ПОЛИЦИИ ОСОБОГО НАЗНАЧЕНИЯ}

Аннотация. Деятельность бойцов спецподразделений, связана с риском для жизни и характеризуется частым возникновением экстремальных ситуаций, осуществляется в напряженных меняющихся условиях, не регламентирована жестким распорядком дня, связана с постоянным ношением и возможным применением оружия, с реализацией властных полномочий.

Различным аспектам проблемы профессиональной и функциональной надежности в системе правоохранительных органов посвящены работы отечественных и зарубежных ученых, в работах которых освещены лишь отдельные вопросы психологических особенностей деятельности специалистов правоохранительной деятельности в экстремальных условиях.

Основными психологическими характеристиками, которые выделяют профессиональную деятельность полиции особого назначения среди других видов профессиональной деятельности, являются: направленность на обеспечение законности и соблюдения прав человека; необходимость быстро принимать решения и высокая ответственность за них; властные полномочия; эмоциональная насыщенность и напряженность, психофизические нагрузки; наличие организационных и экстремальных факторов; специфичность объектов профессиональной деятельности; толерантность к неопределенным ситуациям; значимость эффективного лидерства и командного взаимодействия в подразделенияX.

Среди наиболее распространенных психологических составляющих причин гибели и ранений сотрудников спецподразделений при исполнении служебных обязанностей определяют: просчеты планирования мероприятий оперативно-розыскной деятельности; недостатки осуществления разведывательных мероприятий; неполнота информационноаналитической отработки операций; дефицит времени при принятии оперативных решений; недостаточно квалифицированные действия работников при исполнении запланированных мероприятий.

Следует понимать, что восприятие ситуации как экстремальной обуславливается 
субъективными показателями личности, основанными на ценностно-смысловой, аффективной сферах личности а также собственном приобретенном опыте. В целом, экстремальные ситуации вызывают негативные изменения в когнитивной, эмоциональной, поведенческой сферах психики. Однако, кроме негативного влияния экстремальнопсихологические факторы осуществляют и положительное влияние на психику бойца, при условии достаточного уровня его нравственной и профессиональнопсихологической подготовленности.

Поскольку деятельность специальных подразделений связана с риском для жизни, осуществляется в напряженных меняющихся условиях, поэтому важное значение приобретает наличие сформированной психологической устойчивости бойцов к стрессовым факторам в условиях выполнения профессиональных задач.

Обеспечить сохранение жизни, физическое и психическое здоровье, а также поддержание высокого уровня эффективности профессиональных действий сотрудников полиции особого назначения позволяет система правовых, специальных, тактических, педагогических и психологических мероприятий, которая представляет собой личную профессиональную безопасность. Она основывается на достаточном уровне профессиональной подготовленности бойцов, который предусматривает также владение безопасными ме- тодами профессиональной деятельности, сформированную личностную установку на выживание, психологические качества, которые позволят адекватно оценивать обстановку, управлять чувством страха, принимать быстрые и правильные решения и не терять самообладание в опасных ситуациях.

Таким образом, поведение полицейского в психологически напряженных и экстремальных ситуациях определяется его профессиональной компетентностью, мотивацией и личной психологической подготовленностью, способностью к профессиональной безопасности. Важной предпосылкой высокой надежности личного состава подразделений полиции особого назначения является сформированность у бойцов психологической готовности к выполнению профессиональных задач, наличие комплекса необходимых психофизиологических свойств, профессионально-важных качеств, постоянное профессиональное совершенствование сотрудников а также развитое командное взаимодействие в подразделении.

Дальнейших же исследований требуют вопросы определения четких критериев психологической пригодности к службе в подразделениях, а также прогнозирования успешности и неуспешности профессиональной деятельности сотрудников полиции особого назначения.

Ключевые слова: полиция особого назначения, полицейский, профессиональная деятельность, экстремальные условия, психо- 
логическая устойчивость, психологическая

готовность, личная профессиональная без-

опасность.

Дата отримання статті: 04.05.2018

Дата рекомендації до друку: 15.05.2018

Дата оприлюднення: 24.05.2018 